\title{
Penerapan Model Pembelajaran Tematik dan Metode Bermain Untuk Meningkatkan Minat dan Hasil Belajar Matematika Pada Materi Ajar "Perkalian Bilangan Dua Angka" Siswa Kelas II SDN Dukuhmencek 03 Kabupaten Jember
}

\author{
Amsri Winarsih \\ SDN Dukuhmencek 03, Jember \\ Jln. Ikan Hiu 2, Botosari Dukuhmencek, Sukorambi, Jember
}

\begin{abstract}
Abstrak
Mata pelajaran Matematika perlu diberikan kepada semua peserta didik mulai dari sekolah dasar untuk membekali peserta didik dengan kemampuan berpikir logis, analitis, sistematis, kritis dan kreatif, serta kemampuan bekerjasama. Kompetensi tersebut diperlukan agar peserta didik dapat memiliki kemampuan memperoleh, mengelola dan memanfaatkan informasi untuk bertahan hidup pada keadaan yang selalu berubah, tidak pasti dan kompetitif. Sekolah Dasar (SD) adalah merupakan sekolah formal yang pertama kali yang sangat menentukan untuk sekolah-sekolah jenjang berikutnya dan sangat menentukan pula perwujudan Pendidikan Nasional. Mengingat pentingnya Sekolah Dasar sangat perlu mendapat perhatian dan penanganan yang sungguh-sungguh. Walaupun telah banyak usaha yang dilakukan untuk meningkatkan kualitas jenjang pendidikan tersebut, akan tetapi sampai saat ini masih jauh dengan apa yang diharapkan oleh pemerintah. Adapun rumusan masalah daiam penelitian tindakan kelas ( PTK ) ini adalah sebagai berikut : Penerapan Model Pembelajaran Tematik Dan Metode Bermain Apakah Dapat Meningkatkan Minat Dan Hasil Belajar Matematika Pada Materi Ajar “Perkalian Bilangan Dua Angka " Siswa Kelas II SDN Dukuhmencek 03 Kecamatan Sukorambi Kabupaten Jember Semester Ganjil Tahun Pembelajaran 2014/2015? Tujuan yang diharapkan dalam penelitian tìndakan kelas (PTK) adalah, untuk meningkatkan ketrampilan guru, aktifitas siswa akan hasil belajar siswa dalam pembelajaran matematika melalui Penerapan Model Pembelajaran Tematik dan Metode Bermain Untuk Meningkatkan Minat dan Hasil Belajar Matematika Pada Materi Ajar "Perkalian Bilangan Dua Angka " Siswa Kelas II SDN Dukuhmencek 03. Tehnik penngumpulan data menggunakan tes, obsevasi, catatan lapangaan dan dokumentasi . Hasil penelitian menunjukan bahwa peningkatan hasil belajar siswa pada siklus I rata - rata 62 dengan rincian siswa yang tuntas $41 \%$ (11 anak) dan yang tidak tuntas $59 \%$ (16 anak), dan siklus II mengalami peningkatan menjadi 79,6 dengan rincian yang tuntas $85 \%$ (23 anak ) sedangkan yang tidak tuntas $15 \%$ (4 anak). Data tersebut sudah memenuhi kriteria ketuntasan yang sudah ditetapkan yaitu $85 \%$
\end{abstract}

Kata Kunci : Pembelajaran Tematik, Minat dan Hasil Belajar

\section{Pendahuluan}

Secara Psikologis Masa sekolah di SD khususnya di kelas rendah dengan model pembelajaran tematik, merupakan masa bermain maka setiap kegiatan siswa harus ada unsur bermainnya. Materi akan mudah diterima jika belajar sambil bermain (Semiawan, 1998).Berdasarkan pemikiran itulah maka perlu memilih metode mengajar yakni dalam bentuk permainan. Judul Penelitian Ini Adalah : Penerapan Model Pembelajaran Tematik dan Metode Bermain Untuk Meningkatkan Minat dan Hasil Belajar Matematika Pada Materi Ajar "Perkalian Bilangan Dua Angka " Siswa Kelas II SDN Dukuhmencek 03

Kendala dan masalah yang banyak dihadapi oleh seorang pelajar selain menyangkut macam-macam hal seperti: kesehatan jasmani/rohani, keadaan keuangan, kesulitan rumah tangga, keadaan lingkungan dan sebagainya, juga mengenai persoalan-persoalan cara-cara belajar.

Kesalahan-kesalahan belajar sering dilakukan oleh orang-orang yang tidak memahami cara belajar yang baik. Selain itu masih banyak jenis dan ragamnya kesalahan belajar seperti yang dikemukakan oleh Oemar Hamalik tentang kesalahan umum dalam belajar sebagai berikut: (1) Belajar tanpa mengetahui tujuan yang hendak dicapai; (2) Tidak memiliki motif yang murni atau mungkin belajar tanpa motif tertentu; (3) Belajar dengan kepala kosong, tidak menyadari pengalaman belajarnya di masa lampau; (4) Menganggap bahwa belajar itu sama dengan menghafal (5) Menafsirkan bahwa belajar semata-mata hanya untuk memperoleh pengetahuan saja; (6) Belajar tanpa rencana hanya bersifat incidental; (7) Terlalu mengutamakan satu mata pelajaran saja; (8) Belajar tanpa adanya konsentrasi pikiran dengan sebaik-baiknya hingga bahan yang dipelajari akan sukar melekat; (9) Baru mau belajar setelah dekat dengan waktu akan diadakan ujian atau ulangan".

Adapun tujuan metode bermain adalah "Memberikan kesempatan proses berasosiasi untuk mendapatkan dan memperkaya pengetahuan dengan menggunakan berbagai alat, buku, nara sumber atau tempat. Penggunaan sumber belajar disesuaikan dengan tingkat kebutuhan anak, misalnya ada seorang anak yang hanya menghendaki sumber belajar yang sama".

Fungsi belajar yang lain adalah meningkatkan perkembangan anak dalam berbahasa melalui berkomunikasi dengan mereka tentang hal-hal yang berhubungan dengan sumber belajar atau hal lain. Sedapat mungkin anak dilatih untuk bercerita tentang kejadian yang ia lihat, dengar atau hal-hal lain yang ia rasakan.

Alat permainan berfungsi untuk mengenal lingkungan dan membimbing anak untuk mengenali kekuatan maupun 
kelemahan dirinya. Anak didik secara aktif melakukan kegiatan permainan dan secara optimal menggunakan seluruh panca inderanya secara aktif. Kegiatan atau permainan yang menyenangkan juga akan meningkatkan aktivitas sel otak mereka. Lebih lanjut, keaktifan sel otak akan membantu memperlancar proses pembelajaran.

Tujuan penyusunan dokumen model pengembangan silabus tematik pada kelas awal Sekolah Dasar untuk guru adalah sebagai berikut : (1) Memberikan pengetahuan dan wawasan tentang pembelajaran tematik, (2) Memberikan pemahaman kepada guru tentang pembelajaran tematik yang sesuai dengan perkembangan peserta didik kelas awal Sekolah Dasar, (3) Memberikan ketrampilan kepada guru dalam menyusun perencanaan, melaksanakan dan melakukan penilaian dalam pembelajaran tematik, (4) Memberikan wawasan, pengetahuan dan pemahaman bagi pihak terkait, sehingga diharapkan dapat memberikan dukungan terhadap kelancaran pelaksanaan pembelajaran tematik. Sedangkan tujuan untuk ke siswa adalah : Agar siswa lebih menyukai mata pelajaran matematika yang semula merupakan pelajaran yang paling ditakuti oleh siswa dengan menggunakan metode bermain siswa menjadi senang dan mencintai pelajaran matematika sehingga hasil belajar siswa mengalami peningkatan, sedangkan bagi sekolah akan menjadi sekolah yang inofatif dalam mengembangkan pelajaran matematika sesuai dengan Kurikulum Tingkat Satuan Pendidikan dan tujuan pendidikan yang diharapkan oleh pemerintah akan tercapai , sedangkan bagi orang tua siswa diharapkan dengan hasil penelitian tindakan kelas ini dapat bermanfaat untuk dijadikan pedoman dalam ikut berperan serta bertanggung jawab membantu pembelajaran anak ketika ada di rumah, balk dalam menyiapkan alat-alat pembelajaran yang dimiliki putra-putrinya maupun saranasarana yang lain

\section{Metode Penelitian}

Subjek penelitian dalam penelitian tindakan kelas in adalah guru dan siswa kelas II SDN Dukuhmencek 03, sebanyak 27 siswa yang terdiri dari 14 siswa laki - laki dan 13 siswa perempuan. Teknik pengumpulan data yang dilakukan pada penelitian ini menggunakan Metode observasi, Tes dan Dokumentasi. Jenis penelitian ini menggunakan Penelitian Tindakan Kelas ( PTK ) . Data data yang dikumpulkan (1) Analisa data yang berkaitan dengan keterampilan guru dan aktifitas siswa menggunakan teknik analisis data diskriptif. (2) Analisa data yang berkaitan dengan hasil belajar siswa dalam penelitian ini menggunakan teknik penskoran dan tiap jawaban yang benar diberi skor satu sedangkan yang salah duberi skor nol sehingga jumlah skor yang diperoleh siswa adalah dengan menghitung jumlah banyaknya butir soal yang benar. Adapun Kriteria Ketuntasan Minimal ( KKM ) pelajaran Matematika di SDN Dukuhmencek 03 yakni apabila siswa $<65$ maka termasuk pada kategori tidak tuntas sedangkan yang $>$ dari 65 termasuk katergori tuntas. Adapaun tahapan dalam PTK ini terdiri dari lima tahapan yaitu : refleksi awal, perencanaan, tindakan, observasi dan refleksi. Pembelajaran tematik dengan metode bermain diharapkan (1) Guru menjadi lebih trampil lagi dalam penyampaian materi dan lebih inofatif, (2)
Siswa lebih aktif dan kreatif dalam menerima materi baik melalui individu maupun kelomopok dengan ditandai siswa lebih efektif dan kreatif lagi, (3) $85 \%$ siswa Kelas II SDN Dukuhmencek 03 mengalami ketuntasan belajar sebesar $>65$ dari pembelajaran matematika .

\section{Hasil dan Pembahasan}

\section{Siklus I (Pertama)}

Guru menyusunan Perencanaan Pembelajaran Tematik. Guru menyiapkan perlengkapan papan ekselo dan peraga yang lain dan mareti tentang perkalian .Guru menyiapkan blangko observasi dan blangko evaluasi yang akan digunakan untuk mengobservasi hasil siswa baik individu maupaun kelompok. Guru menjelasakan tujuan yang akan dicapai kegiatan belajar hari ini. Guru membentuk kelompok (7 Kelompok@3-4 anak). Guru memberikan tugas kelompok . Siswa beserta kelompoknya membahas tugas yang diberikan oleh guru atau mendiskusikan tugas guru . Guru keliling membantu dan mengawasi tiap - tiap kelompok, Tiap kelompok mempresentasikan hasil kelompoknya dan kelompok lain memberi tanggapan. Siswa memajang hasil kelompoknya - Guru memberi penilaian berupa simbol bintang untuk kelompok yang berprestasi atau nilainya baik . Guru bersama siswa menarik kesimpulan dan membuat rangkuman dari materi yang dilaksanakan .Guru memberikan penguatan proses dân hasil belajar yang dilakukan oleh siswa. Siswa mengerjakan evaluasi secara individu sebagai pengukur sebarapa jauh tingkat pemahaman siswa terhadap materi yang telah dipelajari . Guru memberikan penugasan untuk belajar dirumah berupa PR . Guru memberikan pesan kepada siswanya dan menyampaikan materi pertemuan berikutnya

Hasil belajar berdasarkan minat belajar siswa ( kognitif) menunjukan $37 \%$ yang diperoleh oleh 10 siswa kurang sungguh - sungguh dan $63 \%$ diperoleh oleh 17 siswa yang sungguh - sungguh menurut table efektivitas termasuk criteria kurang efektif, untuk aspek aktifitas belajar siswa (afektif) menunjukan 52\% yang diperoleh 14 siswa yang kurang sungguh - sungguh dan $48 \%$ diperoleh siswa 13 yang sungguh - sungguh menurut tabel efektivitas termasuk kategori kurang efektif, sedangkan untuk aspek melaksanakan tugas (psikomotor) menunjukan $63 \%$ yang diperoleh oleh 17 siwa yang sungguh - sungguh dan $37 \%$ yang diperoleh oleh 10 siswa yang kurang sungguh sungguh menurut tabel efektivitas juga termasuk kriteria kutang efektif.

Hasil belajar siswa pada mata pelajaran Matematika melalui penerapan model pembelajaran tematik dan metode bermain pada siklus I diperoleh hasil tes evaluasi dengan tema " Lingkungan " yang dilaksanakan pada proses akhir pembelajaran. Jumlah siswa yang mengikuti pembelajaran sebanyak 27 siswa. Data yang diperoleh yaitu 11 siswa dengan prosentase $41 \%$ mendapatkan nilai $>65$ dan termasuk kategori tuntas. Sedangkan 16 siswa dengan prosentase $56 \%$ yang mendapatkan nilai $<65$ dan termasuk kategori tidak tuntas. Nilai rata - rata hasil belajar siswa kelAS II mata pelajaran Matematika dengan Pokok Bahasan : "Perkalian Bilangan Dua Angka " dengan tema" Linkungan " melalui penerapan pembelajaran tematik dan 
metode bermain yang diperoleh nilai tertinggi 100 dan nilai terendah 50 .

Berdasarkan hasil pembelajaran siklus I diperoleh data berupa hasil observasi , ketrampilag guru, aktifitas siswa, dan hasil belajar siswa pada pembelajaran matematika tema "Lingkungan" melalui pembelajaran tematik dan metode bermain . Refleksi ini dilaksanakan oleh peneliti dengan kolabolator untuk menganalisi pelaksanaan pembelajaran yang telah berlangsung. Refleksi digunakan sebagai pertimbangan untuk memperbaiki pembelajaran pada siklus I. Refleksi ini lebih difokuskan pada masalah dan keberhasilan yang muncul selama tindakan - tindakan perbaikan yang dilakukan untuk untuk meningkatkan hasil belajar siswa yaitu meningkatkan ketuntasan klasikal yang sesuai indicator keberhasilan . Dari ketuntasan klasikal sebesar $62 \%$ sampai pada ketuntasan klasikal yang sesuai indikatoir klasikal yaitu $85 \%$. Dengan cara memperbaiki pembelajaran siklus II secara keseluruhan, sehingga mampu mencapai indicator keberhasilan yang telah ditentukan dalam penelitian ini

\section{Siklus II}

Guru menyiapkan perlengkapan alat peraga berupa kartu bola yang akan digunakan untuk media pembelajaran tentang perkalian .Guru menyiapkan blangko observasi dan blangko evaluasi yang akan digunakan untuk mengobservasi hasil siswa secara individu maupun kelompok. Guru membagikan LKS dan tugas kelompok, guru menyuruh beberapa siswa untuk memperagakan penggunaan alat peraga (media) pembelajaran. Guru mengamati perilaku siswa pada saat menggunakan media (alat peraga) . Guru membimbing siswa yang kurang bisa menggunakan alat peraga . Guru memantau diskusi / kerjasama antar siswa pada tiap - tiap kelompok. Guru mengamati pemahaman dari masing - masing siswa. Guru mencatat hasil observasi masing - masing siswa. Guru mengevaluasi hasil observasi siswa . Guru menganalisa metode pembelajara tematik yang disampaikan kepada siswa, dengan demikian guru menemukan kelemahan - kelemahan pada pembelajaran yang berlangsung untuk memperbaiki langkah berikutnya .

Hasil belajar berdasarkan minat belajar siswa ( kognitif) menunjukan $96 \%$ yang diperoleh oleh 26 siswa kurang sungguh - sungguh dan $4 \%$ diperoleh oleh 1 siswa yang sungguh - sungguh menurut table efektivitas termasuk kriteria kurang efektif, untuk aspek aktifitas belajar siswa (afektif) menunjukan $81 \%$ yang diperoleh 22 siswa yang kurang sungguh - sungguh dan $19 \%$ diperoleh oleh 5 siswa yang kurang sungguh - sungguh dan- sungguh menurut table efektivitas termasuk kategori kurang efektif, sedangkan untuk aspek melaksanakan tugas ( psykomotor ) menunjukan $93 \%$ yang diperoleh oleh 25 siwa yang sungguh - sungguh dan $7 \%$ yang diperoleh oleh 2 siswa yang kurang sungguh sungguh menurut table efektivitas juga termasuk kritria kutang efektif ..

Hasil belajar siswa pada mata pelajaran Matematika melalui penerapan model pembelajaran tematik dan metode bermain pada siklus I diperoleh hasil tes evaluasi dengan tema " Lingkungan " yang dilaksanakan pada proses akhir pembelajaran . Jumlah siswa yang mengikuti pembelajaran sebanyak 27 siswa. Data yang diperoleh yaitu 23 siswa dengan prosentase $85 \%$ mendapatkan nilai $>65$ dan termasuk kategori tuntas. Sedangkan 4 siswa dengan prosentase $15 \%$ yang mendapatkan nilai $<65$ dan termasuk kategori tidak tuntas. Nilai rata - rata hasil belajar siswa kelas II mata pelajaran Matematika dengan Pokok Bahasan : "Perkalian Bilangan Dua Angka" dengan tema "Lingkungan" melalui penerapan pembelajaran tematik dan metode bermain yang diperoleh nilai tertinggi 100 dan nilai terendah 50 .

Berdasarkan hasil pembelajaran siklus I diperoleh data berupa hasil observasi , ketrampilan guru, aktifitas siswa, dan hasil belajar siswa pada pembelajaran matematika tema "Lingkungan" melalui pembelajaran tematik dan metode bermain . Refleksi ini dilaksanakan oleh peneliti dengan kolabolator untuk menganalisi pelaksanaan pembelajaran yang telah berlangsung. Refleksi digunakan sebagai pertimbangan untuk memperbaiki pembelajaran pada siklus I. Refleksi ini lebih difokuskan pada masalah dan keberhasilan yang muncul selama tindakan - tindakan perbaikan yang dilakukan untuk untuk meningkatkan hasil belajar siswa yaitu meningkatkan ketuntasan klasikal yang sesuai indikator keberhasilan. Dari ketuntasan klasikal sebesar 62 \% sampai pada ketuntasan klasikal yang sesuai indikatoir klasikal yaitu $85 \%$. Dengan cara memperbaiki pembelajaran siklus II secara keseluruhan, sehingga mampu mencapai indikator keberhasilan yang telah ditentukan dalam penelitian ini yaitu $85 \%$. Berikut data hasil penelitian :

Tabel 1. Deskripsi Hasil Penelitian

\begin{tabular}{|c|c|c|c|c|}
\hline Minat & Siklus & & 10 & $3,7 \%$ \\
\hline Siswa & & II & 26 & $63,0 \%$ \\
\hline Akti & Siklus & I & 14 & $18,5 \%$ \\
\hline Sisw & & II & 22 & $48,0 \%$ \\
\hline & Siklus & I & 17 & $7,4 \%$ \\
\hline Tuga & & II & 25 & $54,00 \%$ \\
\hline
\end{tabular}

\section{Kesimpulan dan Saran}

Berdasarkan hasil analisis data tersebut diatas dalam penelitian maka dapat disimpulkan Penelitian Tindakan Kelas (PTK) sebagai berikut : Penerapan Model Pembelajaran Tematik dan Metode Bermain Dapat Meningkatkan Minat dan Hasil Belajar Matematika Pada Materi Ajar "Perkalian Bilangan Dua Angka "Siswa Kelas II SDN Dukuhmencek 03 Kecamatan Sukorambi Kabupaten Jember Semester Genap Tahun Pembelajaran 2014 / 2015

Berdasarkan hasil penelitian ini, untuk meningkatkan kualitas pembelajaran atau meningkatkan kemampuan kognitif, afektif dan psikomotor, maka penulis memberi saran sebagai berikut : (!)Bagi Guru Matematika sebaiknya menggunakan model Pembelajaran Tematik dalam pembelajaran Matematika dengan maksud menambah wawasan dan pengetahuan dalam mengajar di kelas rendah sehingga diharapkan memberikan dukungan terhadap kelancaran pelaksanaan model pembelajaran tematik , memberikan ketrampilan dalam menyusun perencanaan, melaksanakan dan melakukan penilaian dalam memberikan model pembelajaran tematik, metode permainan perlu untuk dijadikan rujukan pada mata pelajaran lain yang memiliki 
karakteristik yang hampir sama , (2) Bagi siswa perlu adanya kerjasama dari semua pihak yang terkait, diantaranya : orang tua, guru dan lingkungan masyarakat (3) Bagi lembaga pendidikan dapat dijadikan sebagai bahan masukan yang berguna dan sebagai umpan balik bagi kebijaksanaan yang diambil dalam rangka peningkatan belajar mengajar dimasa mendatang khususnya model pembelajaran tematik.

\section{Daftar Pustaka}

[1] A.M. Patty, 1992.Permainan untuk segala usia. PT. BPK Gunung_ Mulia, Jakarta

[2] Depdiknas. 2003. Kurikulum Tingkat Satuan Pendidikan Sekolah Dasar (Standart Kompetensi Mata Pelajaran Bahasa Indonesia). Jakarta : Depdiknas.

[3] Anggani Sudono, 2003.Sumber Belajar dan Alat Permainan untuk pendidikan usia dini, PT. Gramedia, Jakarta.

[4] E. Richard Churchill, Bagaimana membuat Trik Permainan dan Tipuan Penglihatan, PT. Angkasa, Bandung.

[5] Kathi Wagner - Aubrey Wagner, 2004.100 Permainan Otak untuk Anak, Platinum.

[6] Ladislaus Naisaban, 2002. 100 Permainan Rakyat, Grasindo, Jakarta. Oemar Hamalik, 2001. Proses Belajar Mengajar, Bumi Aksara, Bandung. 